\title{
Determinan Profitablitas: Risiko Pembiayaan, Capital Adequacy Ratio Dan Operational Efficiency Ratio (Studi Empiris Pada Bank Perkreditan Rakyat Syariah di Provinsi Banten Yang Terdaftar di OJK Periode Januari 2017 - September 2019) Arief Rahman Firmansyah", Dian Maulita ${ }^{2}$ Universitas Serang Raya ${ }^{1}$, Universitas Serang Raya ${ }^{2}$ ariefrf11@gmail.com ${ }^{1}$, maulita.dian@gmail.com ${ }^{2}$
}

\begin{abstract}
Abstrak: Penelitian ini bertujuan untuk mengetahui pengaruh risiko pembiayaan, capital adequacy ratio dan operational efficiency ratio terhadap profitabilitas.

Metode yang digunakan pada penelitian ini adalah metode kuantitatif. Desain penelitian ini adalah asosiatif jenis kausal (hubungan sebab akibat). Populasi dalam penelitian ini adalah Bank Perkreditan Rakyat Syariah di Provinsi Banten yang terdaftar di OJK pada periode Januari 2017 - September 2019. Teknik pengambilan sampel pada penelitian ini menggunakan teknik sampel jenuh yang menghasilkan 88 sampel penelitian. Data yang digunakan dalam penelitian ini adalah data sekunder berupa laporan keuangan triwulan. Teknik pengumpulan data yang digunakan adalah studi pustaka dimana peneliti menghimpun informasi relevan yang berkaitan dengan topik atau masalah yang akan atau sedang diteliti. Analisis data yang digunakan pada peneilitian ini melalui Uji Statistik Deskriptif, Uji Asumsi Klasik, Regresi Berganda, Uji t tabel, Uji F tabel dan Uji Koefisien Determinasi yang diolah melalui SPSS Versi 25.

Berdasarkan hasil penelitian dapat disimpulkan bahwa: 1) tidak terdapat pengaruh Non Performing Finance terhadap Return On Assets, 2) terdapat pengaruh yang signifikan Capital Adequacy Ratio terhadap Return On Assets, 3) terdapat pengaruh yang signifikan Operational Efficiency Ratio terhadap Return On Assets, dan 4) terdapat pengaruh yang signifikan Non Performing Finance, Capital Adequacy Ratio, dan Operational Efficiency Ratio terhadap Return On Assets
\end{abstract}

Kata Kunci: Non Performing Finance, Capital Adequacy Ratio, Operational Efficiency Ratio, Return On Assets.

Salah satu indikator untuk menilai kinerja keuangan suatu bank adalah melihat tingkat profitabilitasnya. Hal ini terkait sejauh mana bank menjalankan usahanya secara efisien. Efisiensi diukur dengan membandingkan laba yang diperoleh dengan aktiva atau modal yang menghasilkan laba. Semakin tinggi profitabilitas suatu bank, maka semakin baik pula kinerja bank tersebut. Return on Assets (ROA) digunakan untuk mengukur profitabilitas bank, karena suatu bank diukur dengan aset yang dananya sebagian besar dari dana simpanan masyarakat. Semakin besar Return on Assets (ROA) suatu bank, semakin besar pula tingkat keuntungan yang dicapai bank, maka semakin baik posisi bank tersebut dari segi penggunaan asset. (Lukman Dendawijaya, 2009 : 118).

Gambaran mengenai kinerja bank dapat dilihat dari laporan keuangan bank tersebut. Terdapat rasio-rasio yang dipergunakan untuk menilai tingkat kesehatan bank yaitu rasio NPF, CAR, OER dan ROA. 
Tabel 1

Non Performing Finance (NPF), Capital Adequacy Ratio (CAR), Operational Efficiency Ratio (OER) Dan Return On Assets (ROA) di Provinsi Banten

\begin{tabular}{|c|c|c|c|c|c|c|}
\hline \multirow{2}{*}{ NO } & \multirow{2}{*}{$\begin{array}{c}\text { NAMA } \\
\text { INSTANSI } \\
\end{array}$} & \multirow{2}{*}{ TAHUN } & \multicolumn{4}{|c|}{ RASIO } \\
\hline & & & NPF & CAR & OER & $\mathrm{ROA}$ \\
\hline \multirow{3}{*}{1} & \multirow{3}{*}{ BPRS MUAMALAH CILEGON } & 2017 & 19,92 & 31,50 & 65,19 & 1,72 \\
\hline & & 2018 & 17,63 & 30,25 & 65,37 & 1,63 \\
\hline & & 2019 & 12,51 & 31,54 & 63,17 & 1,98 \\
\hline \multirow{3}{*}{2} & \multirow{3}{*}{ BPRS CILEGON MANDIRI } & 2017 & 32,39 & 87,40 & 62,93 & 6,11 \\
\hline & & 2018 & 26,14 & 82,21 & 72,30 & 3,86 \\
\hline & & 2019 & 12,05 & 75,55 & 84,71 & 0,00 \\
\hline \multirow{3}{*}{3} & \multirow{3}{*}{ BPRS ATTAQWA } & 2017 & 16,67 & 31,45 & 48,60 & 3,54 \\
\hline & & 2018 & 9,88 & 29,25 & 42,52 & 2,87 \\
\hline & & 2019 & 10,85 & 25,00 & 45,76 & 1,69 \\
\hline \multirow{3}{*}{4} & \multirow{3}{*}{ BPRS WAKALUMI } & 2017 & 9,16 & 9,24 & 64,91 & 2,24 \\
\hline & & 2018 & 8,50 & 17,47 & 63,31 & 0,77 \\
\hline & & 2019 & 9,35 & 28,81 & 71,52 & $-0,55$ \\
\hline \multirow{3}{*}{5} & \multirow{3}{*}{ BPRS MULIA BERKAH ABADI } & 2017 & 3,45 & 8,68 & 36,49 & 2,77 \\
\hline & & 2018 & 2,31 & 11,70 & 30,24 & 3,51 \\
\hline & & 2019 & 1,77 & 12,71 & 35,40 & 0,52 \\
\hline \multirow{3}{*}{6} & \multirow{3}{*}{ BPRS BERKAH RAMADHAN } & 2017 & 13,96 & 6,59 & 68,40 & $-1,66$ \\
\hline & & 2018 & 58,01 & 7,82 & 86,36 & $-1,36$ \\
\hline & & 2019 & 26,82 & 12,00 & 89,42 & $-1,77$ \\
\hline \multirow{3}{*}{7} & \multirow{3}{*}{ BPRS MUSYARAKAH UMMAT INDONESIA } & 2017 & 20,54 & 10,48 & 82,52 & $-0,29$ \\
\hline & & 2018 & 8,65 & 19,89 & 54,22 & 1,15 \\
\hline & & 2019 & 7,91 & 3,00 & 51,98 & 0,42 \\
\hline \multirow{3}{*}{8} & \multirow{3}{*}{ BPRS HARTA INSAN KARIMAH } & 2017 & 26,36 & 16,09 & 39,01 & $-0,37$ \\
\hline & & 2018 & 26,88 & 16,32 & 47,80 & 0,83 \\
\hline & & 2019 & 20,58 & 14,29 & 43,35 & 1,19 \\
\hline
\end{tabular}

Sumber : OJK Laporan Keuangan Triwulan (Data Diolah)

Dapat dilihat dari Tabel 1 diatas, rasio keuangan Bank Perkreditan Rakyat Syariah di Provinsi Banten pada laporan keuangan triwulan periode 2017 - September 2019 berfluktuatif dan bahkan hanya 3 dari 8 BPRS yang tetap konsisten menjaga Return On Assetsnya cukup baik yaitu BPRS Muamalah Cilegon, BPRS Attaqwa dan BPRS Mulia Berkah Abadi

Non Performing Financing (NPF) merupakan pembiayaan macet dimana hal tersebut mempengaruhi laba bank syariah. Pembiayaan macet mencerminkan pembiayaan yang disalurkan oleh bank syariah kepada nasabah yang tidak memenuhi syarat yang diperjanjikan. Menurut Mahardika (2015:179) semakin tinggi NPF mengindikasikan tingginya tingkat pembiayaan bermasalah dan juga mengindikasikan rendahnya kualitas proses penyaluran pembiayaan bank syariah. Oleh karenanya Kasmir (2012:76) mengatakan semakin tinggi rasio ini maka akan semakin buruk kuallitas kredit bank yang menyebabkan jumlah kredit bermasalah semakin besar, dan oleh karena itu bank harus menanggung kerugian dalam kegiatan operasionalnya sehingga berpengaruh terhadap 
penurunan laba (profitabilitas) yang diperoleh bank. NPF mencerminkan risiko pembiayaan, semakin tinggi rasio ini, menunjukkan kualitas pembiayaan bank syariah semakin buruk. Pengelolaan pembiayaan sangat diperlukan oleh bank, mengingat fungsi pembiayaan sebagai penyumbang pendapatan terbesar bagi bank syariah. Tingkat kesehatan pembiayaan (NPF) ikut mempengaruhi pencapaian laba bank.

Penelitian terdahulu NPF yang dapat atau tidak mempengaruhi ROA yaitu : Penelitian Nur Kholis dan Lintang Kurniawati (2018) memperlihatkan bahwa NPF berpengaruh terhadap ROA. Sedangkan penelitian Widiya Ningsih, dkk (2016) memperlihatkan bahwa NPF tidak berpengaruh terhadap ROA.

Capital Adequacy Ratio (CAR) dalam menghasilkan laba dengan mencerminkan modal sendiri perusahaan. Semakin besar CAR maka semakin besar kesempatan bank dalam menghasilkan laba karena dengan modal yang besar, manajemen bank sangat leluasa dalam menempatkan dananya kedalam aktivitas investasi yang menguntungkan. Rendahnya CAR dikarenakan peningkatan ekspansi aset berisiko yang tidak diimbangi dengan penambahan modal dengan demikian dapat menurunkan kesempatan bank untuk berinvestasi dan dapat menurunkan kepercayaan masyarakat kepada bank sehingga berpengaruh pada profitabilitas (Wibowo dan Syaichu ,2013). CAR mencerminkan modal sendiri perusahaan untuk mengahasilkan laba. Semakin besar CAR maka semakin besar kesempatan bank dalam menghasilkan laba karena dengan modal yang besar, manajemen bank sangat leluasa dalam menempatkan dananya kedalam aktivitas investasi yang menguntungkan. Rendahnya CAR dikarenakan peningkatan ekspansi aset beresiko yang tidak diimbangi dengan penambahan modal menurunkan kesempatan bank untuk berinvestasi dan dapat menurunkan kepercayaan masyarakat kepada bank sehingga berpengaruh pada profitabilitas (Werdaningtyas, 2002).

Menurut Dendawijaya (2005:119) rasio biaya operasional adalah perbandingan antara biaya operasional dan pendapatan operasional. Rasio biaya operasional digunuakan untuk mengukur tingkat efisiensi dan kemampuan bank dalam melakukan kegiatan operasinya. Mengingat kegiatan utama bank pada prinsipnya adalah bertindak sebagai perantara, yaitu menghimpung dana (misalnya dana masyarakat), maka biaya dan pendapatan operasional bank didominasi oleh biaya bunga dan hasil bunga Semakin kecil rasio ini berarti semakin efisien biaya operasional yang dikeluarkan bank yang bersangkutan (Almilia dan Herdiningtyas, 2005:138). Rasio BOPO atau OER menunjukkan efisiensi bank dalam menjalankan usaha pokoknya terutama kredit, dimana bunga kredit menjadi pendapatan terbesar perbankan. Semakin kecil OER menunjukkan semakin efisien bank dalam menjalankan aktivitas usahanya. Dengan kata lain BOPO berhubungan positif terhadap profitabilitas bank. 
Penelitian terdahulu OER yang dapat atau tidak mempengaruhi ROA yaitu : Penelitian Fivi Fariha (2016) memperlihatkan bahwa OER berpengaruh terhadap ROA. Sedangkan penelitian Widiya Ningsih, dkk (2016) memperlihatkan bahwa OER tidak berpengaruh terhadap ROA.

Penelitian ini bertujuan untuk menganalis pengaruh risiko pembiayaan, Capital Adequacy Ratio dan Operational Efficiency Ratio serta pengaruhnya terhadap profitabilitas.

\section{METODE}

Metode yang digunakan dalam penelitian ini adalah Sampling Jenuh. Sampling jenuh adalah teknik penentuan sampel bila semua anggota populasi digunakan sebagai sampel. Sampel jenuh juga sering diartikan sampel yang sudah maksimum, ditambah berapapun tidak akan mengubah keterwakilan. (Sugiyono, 2017)

Berdasarkan hal tersebut terdapat 88 sampel dari jumlah populasi sebanyak 8 Bank Perkreditan Rakyat Syariah yang digunakan dalam penelitian ini yaitu : BPRS Cilegon Mandiri, BPRS Muamalah Cilegon, BPRS Musyarakah Ummat Indonesia, BPRS Harta Insan Karimah, BPRS Mulia Berkah Abadi, BPRS Attaqwa, BPRS Wakalumi, BPRS Berkah Ramadhan.

Teknik analisis yang dipergunakan dalam penelitian ini adalah teknik analisis regresi berganda. Sebelum di uji menggunakan regresi berganda terlebih dahulu di uji menggunakan uji statistik dan uji asumsi klasik.

\section{HASIL}

1. Statistik Deskriptif

\section{Tabel 2}

Hasil Uji Deskriptif

Descriptive Statistics

\begin{tabular}{l|r|r|r|r|r|r|} 
& N & Minimum & Maximum & \multicolumn{1}{c|}{ Sum } & \multicolumn{1}{c|}{ Mean } & Std. Deviation \\
\hline ROA & 86 & $-5,67$ & 8,36 & 117,77 & 1,3694 & 2,28971 \\
\hline NPF & 86 & 1,58 & 66,89 & 1469,28 & 17,0847 & 13,33134 \\
\hline CAR & 86 &, 00 & 91,95 & 2275,47 & 26,4590 & 23,49276 \\
\hline OER & 86 & 24,03 & 158,70 & 5077,65 & 59,0424 & 20,24434 \\
\hline Valid N (listwise) & 86 & & & & & \\
\hline
\end{tabular}

Dapat di lihat pada Tabel 2 menjelaskan jumlah data pada penelitian sebanyak 86. Adapun penjelasan deskriptif statistik setiap variabel adalah sebagai berikut :

1. Pada variabel Non Performing Finance (X1) nilai minimum pada variabel tersebut yaitu 1,58. Nilai maksimumnya yaitu 66,89. Nilai keseluruhan 117,77. Untuk rata rata variabel tersebut yaitu 1,3694. Dan untuk standar deviasi dari variabel yaitu 2,28971.

2. Pada variabel Capital Adequacy Ratio (X2) nilai minimum pada variabel tersebut yaitu 0,00 . Nilai maksimumnya yaitu 91,95 . Nilai keseluruhan yaitu 2275,47 . Untuk rata rata variabel tersebut yaitu 17,0874. Dan untuk standar deviasi dari variabel yaitu 13,33134. 
3. Pada variabel Operational Efficiency Ratio (X3) nilai minimum pada variabel tersebut yaitu 24,03 . Nilai maksimumnya yaitu 158,70 . Nilai keseluruhan yaitu 5077,65. Untuk rata rata variabel tersebut yaitu 59,0424. Dan untuk standar deviasi dari variabel yaitu 20,24434.

4. Pada variabel Return On Assets ( $\mathrm{Y}$ ) nilai minimum pada variabel tersebut yaitu $-5,67$. Nilai maksimumnya yaitu 8,36 . Nilai keseluruhan 117,77. Untuk rata rata variabel tersebut yaitu 1,3694. Dan untuk standar deviasi dari variabel yaitu 2,28971.

2. Uji Asumsi Klasik

a. Uji Normalitas

Tabel 3

Hasil Uji Normalitas

One-Sample Kolmogorov-Smirnov Test

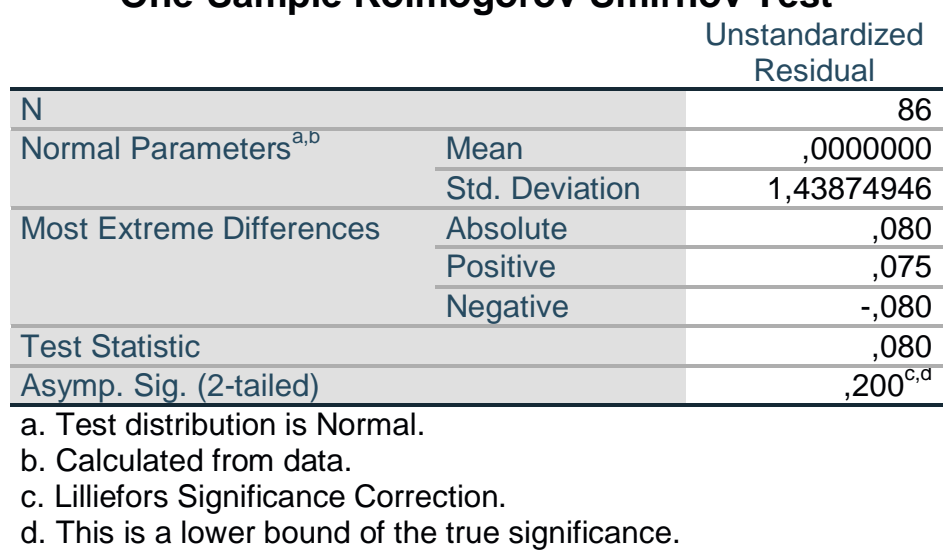

Dapat di lihat pada Tabel 3 nilai Asymp. Sig memiliki nilai > 0,05 yaitu sebesar 0,200 dengan jumlah data sebesar 86 . Hal ini menunjukkan bahwa data yang digunakan pada penelitian ini terdistribusi secara normal.

b. Uji Autikorelasi

Tabel 4

Hasil Uji Autokorelasi

Model Summary

\begin{tabular}{l} 
Model \\
\hline 1 \\
$\begin{array}{l}\text { a. Predictors: (Constant), OER, CAR, NPF } \\
\text { b. Dependent Variable: ROA }\end{array}$
\end{tabular}

Dapat di lihat pada Tabel 4 menunjukkan bahwa nilai Durbin Watson yaitu 1,781. Kemudian untuk dasar pengambilan keputusan berdasarkan $\mathrm{K}(3)$ dan $\mathrm{N}(86)$ dengan signifikasi $5 \%$ dapat menghasilkan nilai du yang berasal dari tabel Durbin Watson yaitu 1,7221. Maka di peroleh bahwa nilai du $(1,7221)<$ Durbin Watson $(1,781)<4$-du $(2,2779)$. Sehingga dapat di ketahui tidak terjadinya autokorelasi. 
c. Uji Multikolinieritas

Tabel 5

Hasil Uji Multikolinieritas

Coefficients $^{a}$

\begin{tabular}{|c|c|c|c|}
\hline \multirow{2}{*}{\multicolumn{2}{|c|}{ Model }} & \multicolumn{2}{|c|}{ Collinearity Statistics } \\
\hline & & Tolerance & VIF \\
\hline \multirow[t]{4}{*}{1} & (Constant) & & \\
\hline & NPF & ,758 & 1,320 \\
\hline & CAR & ,958 & 1,044 \\
\hline & OER & ,753 & 1,328 \\
\hline
\end{tabular}

a. Dependent Variable: $\mathrm{ROA}$

Dapat di lihat pada Tabel 5 menunjukkan bahwa variabel variabel independen memiliki nilai Tolerance $>0,10$ dan nilai VIF < 10. Maka model dinyatakan tidak terdapat gejala multikolonieritas.

d. Uji Heteroskedastisitas

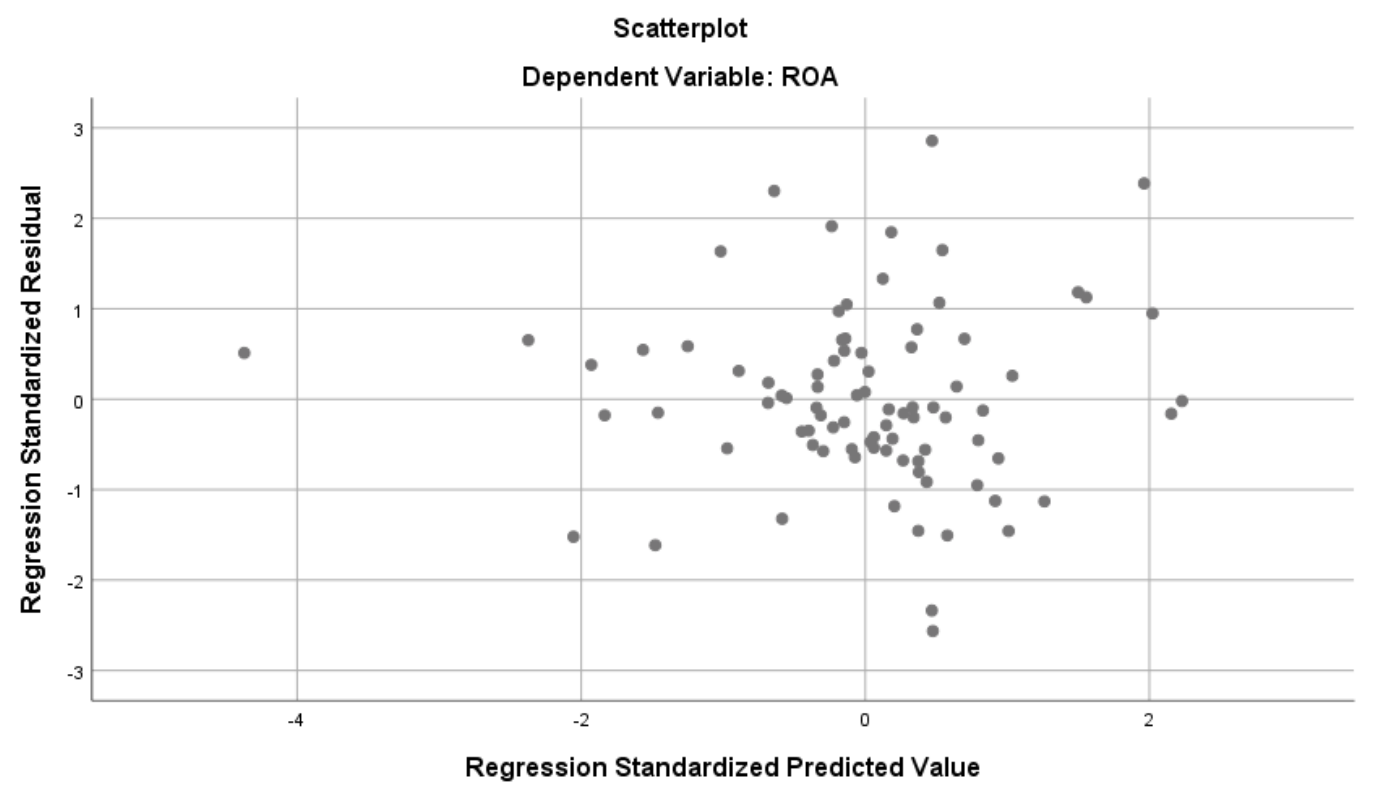

Gambar 1

Hasil Uji Heteroskedastisitas

Dapat di lihat pada gambar 1, menunjukkan titik - titik menyebar secara acak, serta tersebar baik diatas maupun dibawah angka 0 (nol) pada sumbu Y. Hal ini dapat disimpulkan bahwa tidak terjadi heteroskedastisitas pada model regresi, sehingga model regresi layak dipakai untuk penelitian. 
3. Analisis Regresi Berganda

Tabel 6 Hasil Uji Regresi Berganda Coefficients $^{a}$

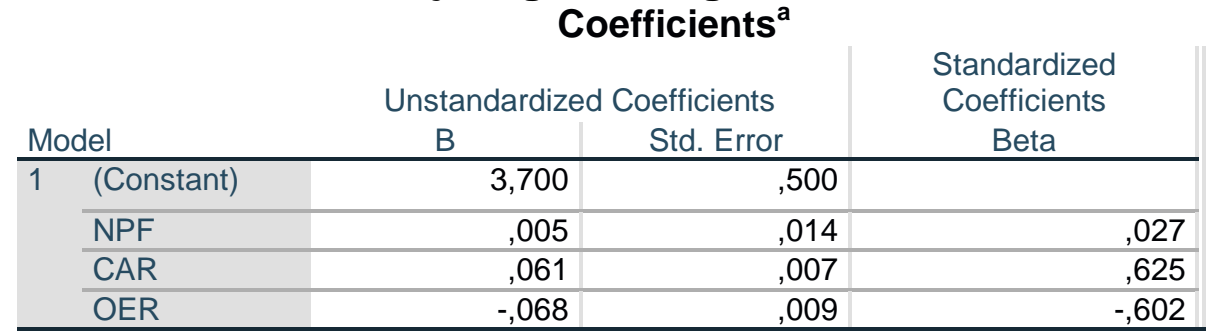

a. Dependent Variable: ROA

Berdasarkan pada Tabel 6 dapat dirumuskan suatu persamaan regresi sebagai berikut :

$$
Y=3,700+0,005 N P F+0,061 C A R-0,0680 E R+e
$$

Dari persamaan regresi berganda tersebut, maka dapat dijelaskan sebagai berikut:

1. Nilai Konstanta menunjukkan angka yang positif, hal ini berarti dengan mengasumsikan ketiadaan variabel independen maka Return On Assets akan menghasilkan angka sebesar 3,700

2. Non Performing finance (X1) memiliki nilai koefisien regresi sebesar 0,005 . Maksudnya adalah jika $X 1$ naik satu (1) maka akan di ikuti oleh peningkatan Return On Assets sebesar 0,005.

3. Capital Adequacy Ratio (X2) memiliki nilai koefisien regresi sebesar 0,061. Maksudnya adalah jika X2 naik satu (1) maka akan di ikuti oleh peningkatan Return On Assets sebesar 0,061.

4. Operational Efficiency Ratio (X3) memiliki nilai koefisien regresi sebesar - 0,068. Maksudnya adalah jika X3 naik satu (1) maka akan di ikuti oleh penurunan Return On Assets sebesar - 0,068.

4. Uji t atau parsial

\begin{tabular}{|c|c|c|}
\hline & $\begin{array}{c}\text { Tabel } 7 \\
\text { Hasil Uji t } \\
\text { Coefficients }^{a}\end{array}$ & \\
\hline Model & $\mathrm{T}$ & Sig. \\
\hline 1 (Constant) & 7,402 & ,000 \\
\hline NPF & ,340 & ,735 \\
\hline CAR & 8,816 & ,000 \\
\hline OER & $-7,533$ &, 000 \\
\hline
\end{tabular}

a. Dependent Variable: ROA

Berdasarkan pada Tabel 7 dapat di jelaskan sebagai berikut :

1. Pengaruh Non Performing Finance terhadap Return On Assets 
Berdasarkan hasil hitung SPSS diperoleh variabel Non Performing Finance nilai sig yaitu $0,735>0,05$. Sedangkan dengan membandingkan hasil perhitungan di dapatkan nilai $\mathrm{t}$ hitung $=0,340$ dan nilai t tabel $=1,989$ jadi $0,340<1,989$. Hal ini menunjukan bahwa Non Performing Finance tidak berpengaruh signifikan terhadap Profitabilitas.

2. Pengaruh Capital Adequacy Ratio terhadap Return On Assets

Berdasarkan hasil hitung SPSS diperoleh variabel Capital Adequacy Ratio nilai sig yaitu 0,000 < 0,05. Sedangkan dengan membandingkan hasil perhitungan di dapatkan nilai $t$ hitung $=8,816$ dan nilai t tabel $=1,989$ jadi $8,816>1,989$. Hal ini menunjukan bahwa Capital Adequacy Ratio berpengaruh signifikan terhadap Profitabilitas.

3. Operational Efficiency Ratio terhadap Return On Assets

Berdasarkan hasil hitung SPSS diperoleh variabel Operational Efficiency Ratio nilai sig yaitu 0,000 $<0,05$. Sedangkan dengan membandingkan hasil perhitungan di dapatkan nilai $t$ hitung $=7,533$ dan nilai $t$ tabel $=1,989$ jadi $7,533>1,989$. Hal ini menunjukan bahwa Operational Efficiency Ratio berpengaruh signifikan terhadap Profitabilitas.

5. Uji F atau Simultan

Tabel 8 Hasil Uji F

ANOVA $^{a}$

\begin{tabular}{ll|r|r|r|r|r} 
Model & & Sum of Squares & df & Mean Square & F & Sig. \\
\hline 1 & Regression & 269,685 & 3 & 89,895 & 41,895 &, $000^{\circ}$ \\
\cline { 2 - 7 } & Residual & 175,950 & 82 & 2,146 & & \\
\cline { 2 - 7 } & Total & 445,635 & 85 & & & \\
\hline
\end{tabular}

a. Dependent Variable: ROA

b. Predictors: (Constant), OER, CAR, NPF

Berdasarkan tabel 8 dapat di lihat nilai sig $0,000<0,05$.

Sedangkan dengan membandingkan hasil perhitungan di dapatkan nilai $F$ hitung $=41,895$ dan nilai $F$ tabel $=2,716$ jadi $41,895>2,716$. Hal ini menunjukkan bahwa Non Performing Finance, Capital Adequacy Ratio Dan Operational Efficiency Ratio berpengaruh secara simultan terhadap Return On Assets.

6. Koefisien Determinasi $\left(R^{2}\right)$

\section{Tabel 9}

Hasil Uji Koefisien Determinasi Model Summary ${ }^{\mathrm{b}}$

\begin{tabular}{|c|c|c|c|c|}
\hline \multirow{3}{*}{ Model } & \multicolumn{4}{|c|}{ Model Summary } \\
\hline & & & Adjusted R & Std. Error of the \\
\hline & h $70^{a}$ & R square & Square & Estimate \\
\hline 1 &, $778^{\mathrm{a}}$ &, 605 &, 591 & 1,46483 \\
\hline
\end{tabular}


Berdasarkan pada tabel 9 dapat di lihat besarnya Adjusted $R$ square adalah 0,591. Hal ini menunjukkan bahwa 59,1\% Return On Assets dipengaruhi oleh Non Performing Finance, Capital Adequacy Ratio Dan Operational Efficiency Rattio. Sedangkan sisanya $40,9 \%$ dipengaruhi oleh variabel - variabel lain.

\section{PEMBAHASAN}

1. Pengaruh Non Performing Finance Terhadap Return On Assets

Berdasarkan hasil hitung SPSS diperoleh variabel Non Performing Finance nilai sig yaitu 0,735 $>0,05$. Sedangkan dengan membandingkan hasil perhitungan didapatkan nilai t hitung $=0,340$ dan nilai $\mathrm{t}$ tabel $=1,989$ jadi $0,340<1,989$. Hal ini menunjukan bahwa Non Performing Finance tidak berpengaruh signifikan terhadap Profitabilitas. Hasil dalam penelitian ini sesuai dengan Lina Krisnawati (2014), Linda Widyaningrum dan Dina Fitrisia Septiarini (2015), dan Widiya Ningsih, Dkk. (2016). Non Performing Finance tidak mempunyai pengaruh yang signifikan terhadap Return On Assets dapat dikarenakan adanya tingkat pengelolaan operasional BPRS yang baik. Sehingga bertambahnya Non Performing Finance pada bank menjadi tidak berpengaruh terhadap Return On Assets karena bertambahnya Non Performing Finance dibarengi dengan adanya efisiensi pengelolaan kinerja operasional bank.

2. Pengaruh Capital Adequacy Ratio Terhadap Return On Assets

Berdasarkan hasil hitung SPSS diperoleh variabel Capital Adequacy Ratio nilai sig yaitu 0,000 <0,05. Sedangkan dengan membandingkan hasil perhitungan didapatkan nilai t hitung $=8,816$ dan nilai $t$ tabel $=1,989$ jadi 8,816 $>1,989$. Hal ini menunjukan bahwa Capital Adequacy Ratio berpengaruh signifikan terhadap Profitabilitas. Hasil dalam penelitian ini sesuai dengan Ria Marliana (2015), dan Indah Lestari (2016). Capital Adequacy Ratio merupakan indikator terhadap kemampuan bank untuk menutupi penurunan aktivanya sebagai akibat dari kerugian-kerugian bank yang disebabkan oleh aktiva yang berisiko dengan kecukupan modal yang dimilikinya. Selain itu, bank memiliki fungsi untuk menghimpun dana dari masyarakat dan kemudian dikembalikan lagi dalam bentuk pinjaman. Dengan demikian, apabila bank memiliki modal yang cukup dalam pemberian pinjaman kepada msayarakat, maka bank juga akan memperoleh keuntungan dari hasil kegiatan operasionalnya tersebut yang mana keuntungan yang diperoleh dapat meningkatkan laba atau profitabilitas bank itu sendiri. Berdasarkan penjelasan tersebut maka dapat dikatakan bahwa semakin tinggi Capital Adequacy Ratio maka semakin tinggi pula Return On Assets.

3. Pengaruh Operational Efficiency Ratio Terhadap Return On Assets 
Berdasarkan hasil hitung SPSS diperoleh variabel Operational Efficiency Ratio nilai sig yaitu 0,000 <0,05. Sedangkan dengan membandingkan hasil perhitungan didapatkan nilai t hitung $=7,533$ dan nilai $\mathrm{t}$ tabel $=1,989$ jadi $7,533>1,989$. Hal ini menunjukan bahwa Operational Efficiency Ratio berpengaruh signifikan terhadap Profitabilitas. Hasil dalam penelitian ini sesuai dengan Lina Krisnawati (2014), Ria Marliana dan Edy Anan (2015), Linda Widyaningrum dan Dina Fitrisia Septiarini (2015), Widiya Ningsih, Dkk. (2016), Fivi Fariha (2016), Refi Rizkika, Dkk. (2017), dan Faizah Nabila Mubarak (2019). Dalam penelitian ini menggambarkan adanya hubungan negatif antara efisiensi operasional dengan profitabilitas, hal tersebut menjelaskan bahwa biaya operasional yang dikeluarkan memiliki jumlah yang sedikit, dengan begitu pendapatan yang diperoleh dari hasil kegiatan operasional bank akan bertambah sehingga dapat berdampak pada peningkatan profitabilitas bank. Jadi, semakin rendahnya rasio OER maka dengan begitu dapat meningkatkan profitabilitas bank. Hal ini berhubungan dengan efisiensi operasional bank, rasio BOPO yang tinggi menunjukkan bahwa bank belum mampu memanfaatkan dan menggunakan sumber daya yang dimiliki secara baik dan benar atau dapat dikatakan belum mampu menjalankan kegiatan usahanya secara efisien, sebaliknya rasio BOPO yang rendah mengindikasikan bahwa bank tersebut telah mampu menjalankan usahanya secara efisien.

4. Pengaruh Non Performing Finance, Capital Adequacy Ratio Dan Operational Efficiency Ratio Terhadap Return On Assets

Berdasarkan hasil hitung SPSS diperoleh nilai sig $0,000<$ 0,05 . Sedangkan dengan membandingkan hasil perhitungan di dapatkan nilai $F$ hitung $=41,895$ dan nilai $F$ tabel $=2,716$ jadi 41,895 > 2,716. Hal ini menunjukkan bahwa Non Performing Finance, Capital Adequacy Ratio Dan Operational Efficiency Ratio berpengaruh secara simultan terhadap Return On Assets. Hasil dalam penelitian ini sesuai dengan Lina Krisnawati (2014), dan Fivi Fariha (2016). Hal tersebut dapat terjadi karena profitabilitas (Return On Assets) pada Bank Perkreditan Rakyat Syariah dipengaruhi oleh semua atau sebagian rasio - rasio keuangan seperti rasio pembiayaan yaitu Non Performing Finance, rasio permodalan yaitu Capital Adequacy Ratio, dan rasio beban operasional yaitu Operational Efficiency Ratio.

\section{KESIMPULAN}

Berdasarkan hasil pengujian dan pembahasan pada bagian bagian sebelumnya, maka dapat disimpulankan sebagai berikut :

1. Non Performing Finance tidak berpengaruh signifikan terhadap Return On Assets. 
2. Capital Adequacy Ratio berpengaruh signifikan terhadap Return On Assets.

3. Operational Efficiency Ratio berpengaruh signifikan terhadap Return On Assets.

4. Non Performing Finance, Capital Adequacy Ratio Dan Operational Efficiency Ratio berpengaruh secara simultan terhadap Return On Assets.

\section{DAFTAR PUSTAKA}

Astarina, Ivalaina dan Hapsila, Angga. (2015). Manajemen Perbankan. Yogyakarta: Deepublish.

Bambang Supomo dan Nur Indriantoro, 2002, Metodologi Penelitian Bisnis, Cetakan Kedua, Yogyakara; Penerbit BFEE UGM.

Dendawijaya, Lukman. (2009). Manajemen Perbankan. Ghalia Indonesia, Jakarta.

Fariha, Fivi. (2016). Pengaruh Capital Adequacy Ratio (CAR), Non Performing Finance (NPF), Dan Biaya Operasional Terhadap Pendapatan Operasional (BOPO) Terhadap Return On Asset (ROA) Pada BPRS Di Indonesia Periode 2012-2015. UIN Syarif Hidayatullah Jakarta

Ghozali, Imam.2012. "Aplikasi Analisis Multivariate dengan Program IBM SPSS 20 Edisi 6". Badan Penerbit Universitas Diponegoro, Semarang.

Gitman, Lawrence J \& Chad J. Zutter. 2012. "Principles of Managerial Finance. Thirteenth Edition". England: Pearson Education.

Hutagalung, Esther Novelina dkk.2013."Analisis Rasio Keuangan Terhadap Kinerja Bank Umum di Indonesia. Jurnal Aplikasi Manajemen".Vol. 11, No. 1.

Ismail. (2010). Manajemen Perbankan Dari Teori Menuju Aplikasi. Jakarta: Kencana.

Kholis, N., \& Kurniawati, L. (2018). Jurnal Ekononomi \& Keuangan Islam. $4(2), 75-80$.

Krisnawati, L. (2014). Pengaruh Modal, Kualitas Aset, dan Efisiensi terhadap Hasil Pengembalian Pada Bank Pembiayaan Rakyat Syariah di Bawah Pengawasan Bank Indonesia. Jurnal Bisnis Dan Manajemen, 2(2), 182-194.

Lestari, Indah. (2016). Pengaruh Dana Pihak Ketiga (DPK), Non Performing Finance (NPF), Capital Adequacy Ratio (CAR) Dan Financaing Deposit Ratio (FDR) Terhadap Return On Asset (ROA) Pada BPRS Di Indonesia Periode 2010-2015. UIN Syarif Hidayatullah Jakarta.

Mawaddah, N. (2015). Faktor-Faktor Yang Mempengaruhi Profitabilitas Bank Syariah. Etikonomi, 14(2).

Mubarak, Faizah Nabila. (2019). Analisis Pengaruh Risiko Likuiditas, Risiko Pembiayaan Dan Risiko Operasional Terhadap Profitabilitas Bank Umum Syariah Di Indonesia Periode 2014-2018. IAIN 
Surakarta.

Ningsih, W., Badina, T., \& Rosiana, R. (2016). Determinan Profitabilitas Bank Pembiayaan Rakyat Syariah Di Indonesia. Jurnal IImu Akuntansi, 9(Oktober), 207-214.

Riyadi, Slamet. (2006). Banking Assets And Liability Management. Jakarta: Lembaga Penerbit Fakultas Ekonomi Universitas Indonesia.

Rizkika, R., \& Dillak, V. J. (2017). Analisis Faktor-Faktor Yang Mempengaruhi Profitabilitas Bank Umum Syariah di Indonesia ( Studi Pada Bank Umum Syariah Yang Terdaftar di Otoritas Jasa Keuangan Selama Tahun 2012-2015 ) ANALYSIS OF THE FACTORS THAT AFFECTING ISLAMIC BANK PROFITABILITY in IN. 4(3), 26752686.

Sari, R. A. (2017). Pengaruh risiko kredit, risiko likuiditas, dan permodalan terhadap profitabilitas perbankan. 13.

Sugiyono. (2017). Metode Penelitian Kuantitatif, Kualitatif, Dan Kombinasi. Bandung: Alfabeta.

Sukarno, Kartika Wahyu \& Muhamad Syaichu. 2006. Analisis FaktorFaktor yang Mempengaruhi Mempengaruhi Kinerja Bank Umum di Indonesia. Jurnal Studi Manajemen \& Organisasi, (Online), Vol. 3, No. 2.

Umi Narimawati, dkk. (2010). Penulisan Karya Ilmia : Panduan Awal Menyusun Skripsi dan Tugas Akhir Aplikasi Pada Fakultas Ekonomi UNIKOM. Bekasi: Penerbit Genesis.

Werdaningtyas, Hesti. (2002). Faktor yang Mempengaruhi Profitabilitas Bank Take Over Pramerger di Indonesia. Jurnal Manajemen Indonesia.

Wibowo, Syaichu. (2013). Analisis Pengaruh Suku Bunga, Inflasi, CAR, BOPO, NPF Terhadap Profitabilitas Bank Syariah, Diponegoro. Journal of Management, Volume 2, Nomor 2, Hal 1-10

Wibowo. (2011). Manajemen Kinerja. Jakarta: PT. Rajagrafindo Persada.

Widyaningrum, L., \& Septiarini, D. F. (2015). Pengaruh CAR, NPF, FDR, dan OER Terhadap ROA Pada Bank Pembiayaan Rakyat Syariah di Indonesia Periode Januari 2009 Hingga Mei 2014. Journal JESTT, 2(12), 970-985. 